\title{
Pengaruh Uang Saku, Pembelajaran Akuntansi Keuangan dan Pengalaman Kerja Terhadap Perilaku Keuangan dengan Literasi Keuangan sebagai Variabel Intervening
}

\author{
Eka Febi Wahyuning Tyas ${ }^{* 1}$, Agung Listiadi ${ }^{2}$ \\ 1,2 Program Studi Pendidikan Akuntansi \\ Universitas Negeri Surabaya \\ Surabaya, Indonesia
}

e-mail: eka.17080304084@mhs.unesa.ac.id ${ }^{* 1}$, agunglistiadi@unesa.ac.id²

Pengutipan

Tyas,E.F.W., \&

Listiadi, A. (2021).

Pengaruh Uang

Saku,

Pembelajaran

Akuntansi

Keuangan dan

Pengalaman

Kerja Terhadap

Perilaku

Keuangan

Dengan Literasi

Keuangan

Sebagai Variabel

Intervening.

Jurnal Pendidikan

Ekonomi

Undiksha, 13(1),

95-107

http://dx.doi.org/1 0.23887/jipe.v13i

1.33751

\begin{abstract}
Abstrak
Riwayat Artikel Tanggal diajukan: 13 April 2021

Tanggal diterima : 30 April 2021

Tanggal dipublikasikan: 25 Juni 2021

Perilaku keuangan setiap orang berbeda seperti yang ditunjukkan oleh kualitas setiap individu. Penelitian tersebut diarahkan untuk mengetahui hasil analisis literasi keuangan memediasi pengaruh uang saku, pembelajaran akuntansi keuangan, dan pengalaman kerja terhadap perilaku keuangan. Lokasi Penelitian di Universitas Negeri Surabaya dengan populasi penelitian mahasiswa pendidikan akuntansi Universitas Negeri Surabaya. Pengujian dilakukan dengan menggunakan teknik purposive sampling dan ukuran sampel ditentukan menggunakan rumus Maholtra untuk mendapatkan jumlah sampel sebanyak 120 responden. Metode pengumpulan data adalah angket dan tes. Dengan teknik analisis data Structural Equation Model menggunakan Warpp/s. Maka dari hasil penelitian dapat diketahui apakah tidak terdapat pengaruh langsung antara uang saku terhadap perilaku keuangan. Sebaliknya, variabel pengalaman kerja dan pembelajaran akuntansi keuangan berpengaruh langsung positif dan signifikan kepada perilaku keuangan. Memiliki pengaruh yang positif dan signifikan antara uang saku terhadap literasi keuangan. Variabel pembelajaran akuntansi keuangan dan pengalaman kerja tidak memiliki rpengaruh terhadap literasi keuangan. Variabel literasi keuangan tidak mempengaruhi perilaku keuangan dan tidak dapat memediasi pengaruh uang saku, pembelajaran akuntansi keuangan, dan pengalaman kerja terhadap perilaku keuangan.
\end{abstract}

Kata kunci: uang saku; belajar akuntansi keuangan; pengalaman kerja; perilaku keuangan; literasi keuangan.

\begin{abstract}
The financial behavior of each person is different as shown by the qualities of each individual. The study was directed to determine the results of the analysis of financial literacy to mediate the effect of pocket money, financial accounting learning, and work experience on financial behavior. Research location at the Universitas Negeri Surabaya with a research population of accounting education students at the Universitas Negeri Surabaya. Tests were carried out using purposive sampling technique and the sample size was determined using the Maholtra formula to obtain a total sample size of 120 respondents. The data collection methods were questionnaires and tests. With the Structural Equation Model data analysis technique using Warppls. So from the research results it can be seen whether there is no direct influence between pocket money on financial behavior. On the other hand, work experience and financial accounting learning variables have a positive and significant direct effect on financial behavior. Has a positive and significant influence between pocket money on financial literacy. Financial accounting learning variables and work experience have no effect on financial literacy. Financial literacy variables do not affect financial behavior and cannot mediate the effect of pocket money, financial accounting learning, and work experience on financial behavior.
\end{abstract}


Keywords: pocket money; learning financial accounting; work experience; financial behavior; financial literacy.

\section{PENDAHULUAN}

Di era zaman milenial ini dimana masyarakat di mudahkan dengan penggunaan smartphone yang melayani beraneka macam informasi yang dapat membawa dampak pengaruh keinginan dalam membeli dengan online seperti makanan, fashion dan sebagainya, Dilihat dari banyaknya penawaran pada smartphone aplikasi media sosial seperti Tokopedia, Lazada, Shope, Traveloka, Go-Jek dan lain-lain. Hal tersebut tentu dapat menarik perhatian pengunjung, khususnya remaja. Maka kebutuhan hidup menjadi tinggi, karena tidak konsistennya harga barang pokok. Sehingga dibutuhkan pengawasan pengeluaran uang dengan teratur (hemat). Hal ini dilakukan untuk menjauhkan perilaku konsumtif. Pola hidup konsumtif merupakan kerutinan setiap individu untuk mengkonsumsi, berbelanja sesuatu dengan berlebihan, namun hal tersebut bukan merupakan kebutuhan tetapi hanya keinginan, seperti yang sedang terjadi dikalangan mahasiswa Fakultas Ekonomi Universitas Negeri Surabaya, dimana mahasiswa memiliki jiwa labil yang mudah tegoda dengan lingkungan terutama dalam berkonsumsi, sedangkan mahasiswa rantau cenderung harus pandai mengelola keuangannya untuk satu bulan kedepan dengan pandai mengatur uang yang diberi orangtuanya.

Mahasiswa mempunyai latar belakang perilaku keuangan yang berbedabeda. Melalui hasil peninjauan, banyaknya jumlah mahasiswa Fakultas Ekonomi Universitas Negeri Surabaya sebagian mendahulukan kepentingan yang tidak utama daripada kebutuhan yang utama. Dilihat dari pemenuhan kebutuhan menurut peninjauan pada 30 mahasiswa 24 dari mahasiswa fakultas ekonomi menyatakan kesulitan mengatur

keuangannya. Baik dari skala prioritas, perencanaan, pengelolaan, dan penggunaan masih belum tepat. Perilaku dalam Keuangan berkaitan dengan mengelola keuangan. Cummins (dalam N. Fatimah and Syamsiyah 2018) menjelaskan untuk menggapai kejayaan yaitu dengan kemampuan seseorang dalam mengatur keuangannya, dengan begitu ilmu tentang pengelolaan mengatur keuangan sangat berharga untuk semua masyarakat, begitu juga mahasiswa. Lina \& Rosyid (1997) menyampaikan bahwa ada sejumlah faktor yang mempengaruhi perilaku menabung seperti variabel dalam, seperti sikap belajar, merupakan faktor yang datang dari luar seperti promosi, kekeluargaan, dan lingkungan Sagita et al. (2018). Hal tersebut diperkuat dengan penjelasan bahwa perilaku keuangan mahasiswa dipengaruhi oleh literasi keuangan, sosialisasi dari wali, pendamping, dan ketenangan.

Mengingat unsur-unsur yang dikemukakan oleh N. Fatimah and Syamsiyah (2018), Lina \& Rosyid (1997) maka faktor pertama yang dianggap mempengaruhi perilaku keuangan mahasiswa adalah literasi keuangan. Literasi keuangan merupakan faktor pertama yang menentukan perilaku siswa. Literasi Keuangan ialah aspek utama untuk menentukan mahasiswa dalam berperilaku. Penting untuk perilaku keuangan untuk mempunyai keterkaitan dengan literasi keuangan, Garman \& Forgue (2010), mengungkapkan pengetahuan yang sesungguhnya tentang literasi keuangan, prinsip, alat teknologi dan konsep yang menjadi dasar untuk pintar dalam memakai uang. Menurut penelitian Maulita \& Mersa (2017), mempererat jika literasi keuangan berpengaruh secara signifikan kepada perilaku menabung. Dengan begitu, literasi keuangan memiliki peran penting untuk memperbaiki perilaku menyimpang yang ada pada diri mahasiswa.

Faktor kedua yang dianggap mempengaruhi perilaku keuangan mahasiswa yaitu Pembelajaran Akuntansi Keuangan yang ada di Fakultas Ekonomi Universitas Negeri Surabaya telah meliputi bidang ilmu ekonomi, tentunya mahasiswa sudah dibekali manajemen dan pendidikan keuangan di perkuliahan diharapkan mampu mengendalikan 
keuangan dengan baik dan dapat memegang putusan keuangan dengan baik maka mahasiswa terbebas dari persoalan keuangan (S. Fatimah, 2018).

Faktor ketiga yang dianggap mempengaruhi perilaku keuangan mahasiswa yaitu wawasan kerja sangat bersangkutan dengan mengelola keuangan pribadi. Menurut Sina (2014) pengalaman memiliki peran utama untuk mengelola keuangan pribadi karena dapat menjadikan proses belajar untuk menciptakan kebebasan keuangan. Kejadian ini dapat dilihat dari kesalahan seseorang dalam mengendalikan keuangan di masa lalunya, Namun hal itu dijadikan pengalaman untuk dijadikan pembelajaran supaya kesalahan tidak kembali terulang di masa depan. Penelitian dari Erskine et al. (2006) mengungkapkan jika remaja pekerja lebih pandai menyisihkan uang dan lebih mengerti masalah keuangan jika dibandingkan dengan remaja yang tidak bekerja. Karena dengan pengalaman kerja mahasiswa menjadi lebih pandai pada perilaku keuangannya dan menjadi lebih waspada membuat keputusan keuangan terkait dengan pemakaian dan mengelola keuangannya.

Faktor keempat yang dianggap mempengaruhi perilaku keuangan siswa adalah pendapatan siswa, yaitu uang saku khusus. Seperti yang ditunjukkan oleh Nidar \& Bestari (2012) mengungkapkan jika uang saku berpengaruh signifikan terhadap literasi keuangan. Dengan pengiriman uang, setiap individu dipersilakan untuk mengawasi dana dengan tepat. Meskipun demikian, hasil penelitian Megasari (2014) mengungkapkan bahwa uang saku memiliki pengaruh yang sangat besar dan terdapat hubungan negatif dengan literasi keuangan. Diklarifikasi bahwa jika uang saku yang lebih rendah, literasi keuangan akan meningkat. Bergantian, jika literasi keuangan berkurang, pengiriman uang akan lebih positif.

Alasan memilih variabel bebas yang meliputi uang saku, pembelajaran akuntansi keuangan, pengalaman kerja yang mempengaruhi perilaku keuangan dengan literasi keuangan sebagai variabel perantara karena kelima faktor tersebut berpengaruh signifikan kepada perilaku keuangan mahasiswa. Selain itu, kelima faktor tersebut memiliki gap hasil penelitian sebagaimana Erawati (2016), Sari (2015) dan S. Fatimah (2018) terdapat pengaruh signifikan kepada perilaku keuangan pembelajaran diperguruan tinggi. Sedangkan penelitian dari Herawati (2015) menyatakan tidak mempunyai dampak yang signifikan kepada perilaku keuangan, pembelajaran di perguruan tinggi.

Hasil dari Nidar \& Bestari (2012) mengungkapkan uang saku secara signifikan memengaruhi literasi keuangan. Uang saku memungkinkan setiap orang untuk mengontrol uang dengan benar, karena dengan ini menyerahkan kesempatan pada para wali untuk terbiasa mengajar anak-anak mereka dengan tepat. Berbeda dengan Megasari (2014), mengklarifikasi jika uang saku memiliki dampak kritis dan memiliki hubungan yang negatif dengan literasi keuangan. Klarifikasi ini diperjelas dengan uang saku yang lebih rendah atau lebih merugikan, litersi keuangan akan lebih banyak. Kebalikannya, jika uang saku makin positif, literasi keuangan akan berkurang.

Menurut penelitian Laily (2014), menunjukkan literasi keuangan merupakan determinan perilaku keuangan, sedangkan Arifin (2017), menjelaskan pengetahuan keuangan dan fokus kendali mempengaruhi perilaku keuangan. Menurut Imawati (2013), Agustina et al. (2018) dan Andrew, Vincentius \& Linawati (2014), mengungkapkan jika informasi keuangan pada dasarnya mempengaruhi perilaku keuangan. Hasil ini (Hafiz, 2015), (Murni, 2017), dan Rizkiana \& Kartini (2017), mengemukakan jika tidak memiliki perbedaan financial behavior menurut tingkat literasi keuangan mahasiswa atau financial literacy tidak mempunyai pengaruh terhadap perilaku keuangan.

Menurut Laily (2014), menjelaskan tidak ada bukti bahwa pengalaman kerja memiliki hubungan dengan perilaku keuangan mahasiswa. Hal ini berlawanan pada penelitian Sabri (2008), Erskine et al. (2006). Selain itu, Laily (2014), 
menjelaskan tidak mempunyai bukti adanya hubungan dengan perilaku keuangan mahasiswa terhadap kemampuan akademis. Bertolak belakang dengan peneliti Susanti (2013), menurutnya memiliki pengaruh perilaku keuangan siswa terhadap pembelajaran ekonomi di sekolah.

Jika dibandingkan dengan penelitian terdahulu ditemukan adanya kelainan dengan hasil riset yang terbukti memiliki pengaruh yang tidak signifikan serta signifikan, jadi peneliti akan mengkaji lebih lanjut lagi terkait perilaku keuangan bagi mahasiswa Fakultas Ekonomi Universitas Negeri Surabaya angkatan 2017 dan 2018 prodi pendidikan akuntansi. Sehubungan dengan kejelasan latar belakang tersebut, maka peneliti melakukan penelitian yang berjudul: "Pengaruh Uang Saku, Pembelajaran Akuntansi Keuangan dan Pengalaman Kerja terhadap Perilaku Keuangan Dengan Literasi Keuangan Sebagai Variabel Intervening" terdiri dari Uang Saku, pembelajaran akuntansi keuangan, pengalaman kerja dan literasi keuangan secara bersamaan memiliki pengaruh terhadap variabel dependen yaitu perilaku keuangan.

Tujuan dilakukannya penelitian oleh peneliti adalah (1). Menganalisis dampak uang saku terhadap perilaku keuangan mahasiswa Pendidikan Akuntansi UNESA, (2). Menganalisis dampak pembelajaran Akuntansi Keuangan terhadap perilaku keuangan mahasiswa Pendidikan Akuntansi UNESA, (3). Menganalisis dampak Pengalaman kerja terhadap perilaku Keuangan mahasiswa Pendidikan Akuntansi UNESA, (4). Menganalisis dampak literasi keuangan pada perilaku keuangan mahasiswa Pendidikan Akuntansi UNESA, (5). Meneliti dampak uang saku terhadap literasi keuangan mahasiswa Pendidikan Akuntansi UNESA, (6). Menganalisis pengaruh pembelajaran akuntansi keuangan terhadap litreasi keuangan mahasiswa Pendidikan Akuntansi UNESA, (7). Menganalisis pengaruh pengalaman kerja terhadap litreasi keuangan mahasiswa Pendidikan Akuntansi UNESA, (8). Meneliti bagian dari literasi keuangan yang memediasi dampak uang saku terhadap perilaku keuangan mahasiswa Pendidikan Akuntansi UNESA, (9). Meneliti situasi literasi keuangan yang memediasi dampak pembelajaran akuntansi keuangan terhadap perilaku keuangan mahasiswa Pendidikan Akuntansi UNESA, (10). Menelaah bagian dari literasi keuangan dalam menengahi dampak pengalaman kerja terhadap perilaku keuangan mahasiswa Pendidikan Akuntansi UNESA.

\section{METODE}

Penelitian ini merupakan riset kuantitatif dengan metode asosiatif/korelasional. Menurut Suryani \& Hendryadi (2015) Penelitian korelasional melakukan dengan mencari pengaruh atau ikatan satu ataupun lebih variabel bebas kepada satu ataupun lebih variabel terikat. Variabel bebasnya ialah uang saku, pembelajaran akuntansi keuangan, dan pengalaman kerja. Sedangkan variabel terikatnya adalah perilaku keuangan. Variabel mediasi yang digunakan yaitu literasi keuangan. Berikut bentuk desain penelitiannya

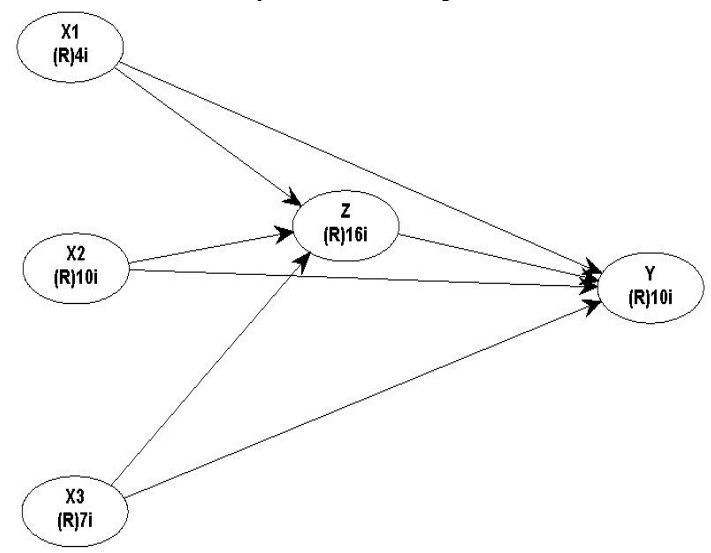

Gambar 1. Desain penelitian

Lokasi penelitian dilakukan di Universitas Negeri. Nanang (2011) mencirikan bahwa populasi merupakan obyek yang ada disekitarnya dan memenuhi kebutuhan tertentu yang diidentikkan dengan persoalan penelitian. Populasi pada penelitian ini ialah mahasiswa Pendidikan Akuntasi angkatan 2017 dan 2018 di Universitas Negeri Surabaya yang berjumlah 159 mahasiswa. Seperti yang diindikasikan oleh A. Murni 
Yusuf, sampel sangat penting bagi populasi yang mewakilkan populasi itu. Ukuran sampel (ukuran size). Pengujian sampel menggunakan teknik purposive sampling. Nanang (2011) mencirikan purposive sampling sebagai metode pemeriksaan dengan perenungan yang berbeda. Kualitas yang ditentukan dalam sampel riset ini antara lain: 1) Mahasiswa aktif program studi Pendidikan Akuntansi Universitas Negeri Surabaya angkatan 2017 dan 2018. 2) Telah menempuh mata kuliah Akuntansi Keuangan. Peneliti memakai rumus Malhotra untuk mencari jumlah sampel yang diperlukan. Menurut teori yang dijelaskan oleh Malhotra (2005) jika jumlah pengujian dengan populasi yang tidak memiliki titik puncak dalam hal apapun adalah empat atau beberapa kali jumlah penanda yang dipertimbangkan. Dalam investigasi ini, ada 24 petunjuk yang membahas faktor-faktor, sehingga kuantitas pengujian dianggap menyikapi jumlah populasi pada 159 individu $(24 \times 5)$. Selain itu, untuk penelitian yang dilakukan oleh peneliti, informasi yang dikumpulkan dari responden yang dianggap pantas untuk diselidiki adalah sebanyak 120 responden yang tersebar dalam empat kelas yaitu PAK 2017 A, PAK 2017 B, PAK 2018 A, dan PAK 2018 B.

Sumber data pada riset ini ialah data primer. Menurut Suryani \& Hendryadi (2015), data yang dijadikan satu dan mengolah sendiri pada suatu organisasi ataupun perorangan langsung dari objeknya merupakan pengertian data primer. Dalam hal ini data primer didapat langsung pada mahasiswa Pendidikan Akuntansi Universitas Negeri Surabaya melalui instrumen penelitian yang diberikan. Peneliti menggunakan Instrumen kuisioner untuk mengukur variabel uang saku, variabel pembelajaran akuntansi keuangan dan variabel perilaku keuangan, serta tes untuk mengukur variabel literasi keuangan. sebelum instrumen penelitian disebarkan kepada responden sebagai sampel penelitian maka dilakukan uji validitas dan uji reliabilitasnya terlebih dahulu untuk mengetahui kevalidan/kesahihan instrumen penelitian tersebut.

The Structural Equation Model (SEM) merupakan teknik analisis data untuk mengenali ikatan variabel bebas meliputi uang saku, pembelajaran akuntansi keuangan dan pengalaman kerja terhadap variabel terikat yaitu perilaku keuangan dengan variabel intervening literasi keuangan. Pengujian hipotesis dilakukan dengan analisis Warppls.

\section{HASIL DAN PEMBAHASAN}

Berdasarkan hasil uji asumsi klasik menyatakan jika setiap variabel sudah memenuhi syarat validitas dan reliabilitas dengan koefisien reliabilitas setiap variabel yaitu (X1) 0.817, (X2) 0.929, (X3) 0.916, (Y) 0.899 dan $(Z)$ 0.820. Adapun koefisien cronbach's alpha setiap variabel antara lain; (X1) 0.695, (X2) 0.914, (X3) 0.892, (Y) 0.870 dan $(Z) 0.766$. Dimana nilai koefisien reliabilitas dan koefisien cronbach's alpha setiap variabel tersebut lebih dari 0.6 sehingga dinyatakan memenuhi syarat.

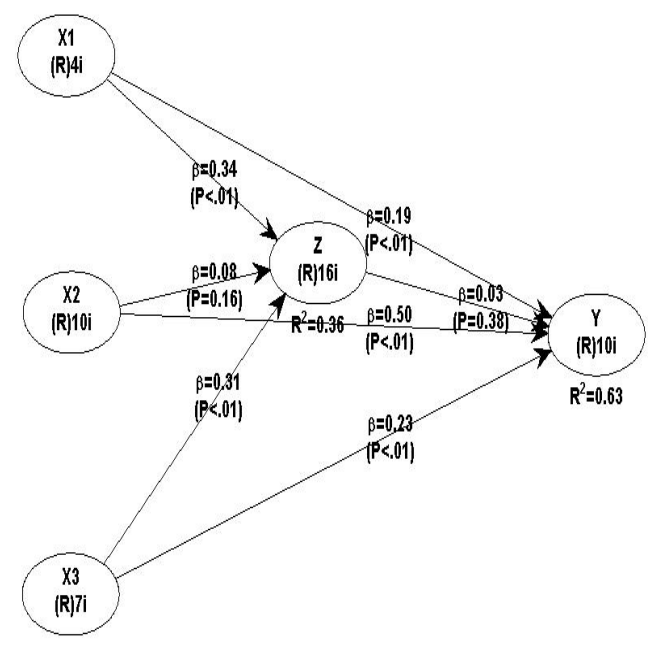

Gambar 2. Pengaruh Langsung Antar Variabel 
Tabel 1. Hubungan Langsung Antara Variabel Penjelas dan Respon

\begin{tabular}{cccccc}
\hline No & $\begin{array}{c}\text { Hubungan antar variabel } \\
\text { (Variabel Penjelas-Variabel } \\
\text { Respon) }\end{array}$ & Koefisien jalur & $p$-value & Keterangan \\
\hline 1 & X1 & Y & 0.195 & 0.009 & Not Significant \\
2 & X2 & Y & 0.502 & $<0.001$ & Significant \\
3 & X3 & Y & 0.234 & 0.002 & Significant \\
4 & X1 & Z & 0.336 & $<0.001$ & Significant \\
5 & X2 & Z & 0.083 & 0.160 & Not Significant \\
6 & X3 & Z & 0.312 & $<0.001$ & Significat \\
7 & Z & Y & 0.025 & 0.383 & Not Significant \\
\hline
\end{tabular}

Sumber : Data diolah peneliti (2021)

Berdasarkan hasil analisisi data melalui Warppls didapatkan bahwa (1). Tidak adanya pengaruh secara signifikan uang saku terhadap perilaku keuangan. Terbukti dari $p$-value sebesar 0.009 dengan koefisien jalur 0.195. Sebab nilai $p$ value lebih besar dari 0.005 jadi dinyatakan not significnat sehingga $\mathrm{Ho}$ diterima dan $\mathrm{Ha}$ ditolak. (2). Memiliki pengaruh positif dan signifikan antara pembelajaran akuntansi keuangan terhadap perilaku keuangan. Hal ini ditunjukkan dengan nilai $p<0,001$, lebih rendah dari 0,005 dan koefisien jalur dengan tanda positif sebesar 0.502, maka dinyatakan significant sehingga $\mathrm{Ha}$ diterima serta Ho ditolak. (3). Ada dampak positif antara pengalaman kerja terhadap perilaku keuangan. Ini dikonfirmasi oleh $p$ value 0,002 yang lebih rendah dari 0,005 dan koefisien jalur dengan tanda positif sebesar 0.234 , maka dinyatakan signifikan maka Ha diterima serta Ho ditolak. (4). Memiliki pengaruh positif serta signifikan antara uang saku terhadap literasi keuangan terbukti dengan nilai $p$-value sebesar $<0.001$ dimana lebih kecil dari 0.005 dan koefisien jalur dengan tanda positif sebesar 0.336 , maka dinyatakan significant sehingga $\mathrm{Ha}$ diterima serta $\mathrm{Ho}$ ditolak. (5). Tidak memiliki pengaruh signifikan antara pembelajaran akuntansi keuangan terhadap literasi keuangan. Ditunjukkan dari $p$-value sebesar 0.160 dengan koefisien jalur 0.083 . Karena nilai $p$-value lebih besar dari 0.005 maka dinyatakan no significant sehingga Ho diterima dan $\mathrm{Ha}$ ditolak. (6). Memiliki dampak positif dan signifikan antara pengalaman kerja pada literasi keuangan terlihat dari $p$-value $<0,001$ yang lebih rendah dari 0.005 dan koefisien jalur dengan tanda positif sebesar 0.312, maka dinyatakan significant sehingga $\mathrm{Ha}$ diterima dan Ho ditolak. (7). Tidak memiliki pengaruh yang besar antara literasi keuangan terhadap perilaku keuangan. Hal ini ditunjukkan oleh nilai $p$-value 0,383 dengan koefisien jalur 0,025 . Karena $p$ value lebih menonjol dari 0,005 , maka hal itu dinyatakan tidak signifikan sehingga $\mathrm{Ho}$ diakui dan Ha ditolak. (8). Tidak memiliki dampak uang saku terhadap perilaku keuangan melalui literasi keuangan. Hal ini terlihat dari $p$-value sebesar 0,444 dengan dampak menyimpang sebesar 0,009. Karena $p$-value lebih besar dari 0,005, maka dinyatakan not significnat sehingga Ho diakui dan Ha ditolak. (9). Tidak ada pengaruh antara pembelajaran akuntansi keuangan terhadap perilaku keuangan melalui literasi keuangan. Hal ini terlihat dari $p$-value sebesar 0,486 dengan indirect effects 0,002. Karena $p$-value lebih menonjol dari 0,005, berarti tidak signifikan, Ho diakui dan Ha ditolak. (10). Tidak ada pengaruh antara pengalaman kerja terhadap perilaku keuangan melalui literasi keuangan. Terbukti dengan nilai $p$-value 0,448 dan dampak menyimpang 0,008. Karena $p$-value lebih besar dari 0,005, maka dinyatakan tidak signifikan sehingga Ho diakui dan Ha ditolak. 
Tabel 2. Hubungan Tidak Langsung Antara Variabel Penjelas dan Respon

\begin{tabular}{cccccc}
\hline No & $\begin{array}{c}\text { Hubungan antar variabel } \\
\text { (Variabel Penjelas-Variabel } \\
\text { Respon) }\end{array}$ & Indirect effects & $p$-value & Keterangan \\
\hline 1 & $\mathrm{X} 1$ & $\mathrm{Y}$ & 0.009 & 0.444 & Not Significant \\
2 & $\mathrm{X} 2$ & $\mathrm{Y}$ & 0.002 & 0.486 & Not Significant \\
3 & $\mathrm{X} 3$ & $\mathrm{Y}$ & 0.008 & 0.448 & Not Significant \\
\hline
\end{tabular}

Sumber : Data diolah peneliti (2021)

\section{Pengaruh Uang Saku Terhadap Perilaku Keuangan}

Hasil analisis melalui Warpp/s menunjukkan jika uang saku tidak berpengaruh secara signifikan terhadap perilaku keuangan mahasiswa. Ditunjukkan dari nilai $p$-value sebesar 0.009 dengan koefisien jalur 0.195. dimana nilai $p$-value lebih besar dari 0.005 maka dinyatakan not significnat sehingga $\mathrm{Ha}$ ditolak dan $\mathrm{Ho}$ diterima. Artinya besar kecilnya uang saku yang diberikan mahasiswa tidak mempengaruhi perilaku keuangan mereka. Semakin besar uang saku mahasiswa bukan berarti perilaku keuangannya semakin baik. Bahkan terkadang mahasiswa dengan uang saku yang besar cenderung ingin meningkatkan pengeluarannya namun tidak sesuai dengan kebutuhannya. Sehingga uang saku yang dimilikinya selalu terasa kurang. Ini menunjukan jika mahasiswa belum mempunyai perilaku keuangan dengan tepat.

Menurut Zulaika (2020), mahasiswa harus dapat mengelola uang saku yang diperoleh dari orang tua dengan benar dan membelanjakannya sesuai dengan kebutuhan. Vhalery et al. (2018) menyatakan bahwa mahasiswa mengetahui cara menggunakan uang saku tetapi tidak mengetahui bagaimana mengelola uang saku mereka. Hasil penelitian ini menunjukkan jika perilaku keuangan tidak dipengaruhi oleh besaran uang saku yang diterima mahasiswa. Uang saku hanya sebagai pendapatan terbesar mahasiswa untuk memenuhi kebutuhan hidupnya tanpa mempengaruhi baik atau tidaknya perilaku keuangan. Hasil ini sesuai dengan Arifin (2017), yang menyatakan individu yang berpendapatan tinggi jarang dapat mengelola keuangannya dengan baik karena tidak memiliki tanggung jawab terhadap keuangannya dan cenderung berpikir pendek. Namun, tidak konsisten dengan Kumalasari (2019), yang mengemukakan bahwa uang saku mempengaruhi perilaku keuangan secara negatif.

\section{Pengaruh Pembelajaran Akuntansi Keuangan Terhadap Perilaku Keuangan \\ Hasil analisis melalui Warppls} menyatakan jika memiliki dampak positif serta signifikan antara pembelajaran akuntansi keuangan terhadap perilaku keuangan. Dibuktikan dengan nilai $p$-value sebesar $<0.001$ yang lebih kecil dari 0.005 dan koefisien jalur dengan tanda positif sebesar 0.502 , maka dinyatakan significant sehingga Ha diterima dan Ho ditolak. Maka jika pembelajaran akuntansi semakin baik maka dengan begitu perilaku keuangan mahasiswanya pun akan semakin baik pula begitupun sebaliknya. Pembelajaran akuntansi keuangan dapat memberikan teori-teori mengenai pengelolaan keuangan kepada mahasiswa yang selanjutnya dapat diterapkan pada perilaku keuangan pribadi mahasiswa dalam kehidupan sehari-hari.

Menurut Herawati (2015), pendidikan tentang dengan keuangan berperan penting dalam memberikan pemahaman, kemampuan, penilaian, dan tindakan terkait keputusan keuangan mahasiswa. Melalui pembelajaran akuntansi keuangan yang didapatkan di perguruan tinggi dengan baik diharapkan pengaplikasian dalam perilaku keuangan pribadi mahasiswa juga makin baik. Hasil penelitian sejalan dengan Nasihah (2019), mengemukakan jika pembelajaran akuntansi keuangan mempengaruhi perilaku keuangan mahasiswa secara signifikan. S. Fatimah (2018), juga 
menyatakan jika perilaku keuangan mahasiswa terpengaruhi oleh pembelajaran akuntansi keuangan.

\section{Pengaruh Pengalaman Kerja Terhadap Perilaku Keuangan \\ Hasil analisis melalui Warpp/s} memperlihatkan bahwa memiliki pengaruh positif antara pembelajaran pengalaman kerja terhadap perilaku keuangan. Dibuktikan dengan nilai $p$-value sebesar 0.002 dimana lebih rendah dari 0.005 dan koefisien jalur dengan tanda positif sebesar 0.234 , maka dinyatakan significant sehingga Ha diterima dan Ho ditolak. Dengan begitu banyaknya pengalaman kerja yang dimiliki mahasiwa maka perilaku keuangan mahasiswa juga akan semakin baik. Dengan pengalaman kerja yang dimiliki mahasiswa dapat merasakan bagaimana susahnya mencari uang, sehingga mereka akan berusaha untuk mengelola keuangan dengan baik.

Menurut Irman (2018), pengalaman kerja dapat menambah ilmu keterampilan dan pengetahuan yang dimiliki seseorang untuk dapat mengembangkan diri. Melalui pengalaman kerja yang dimiliki mahasiswa dapat memperoleh pengetahuan dan keterampilan terkait pengelolaan keuangan yang baik dari tempat ia bekerja sehingga dapat diterapkan untuk mengelola perilaku keuangan pribadinya secara bijak. Hasil penelitian ini sesuai dengan Erawati (2016), yang mengemukakan bahwa pengalaman kerja mempengaruhi perilaku keuangan secara signifikan.

\section{Pengaruh Uang Saku Terhadap Literasi Keuangan}

Hasil analisis melalui Warppls menginformasikan mempunyai pengaruh positif serta signifikan antara uang saku terhadap literasi keuangan terbukti dengan nilai $p$-value sebesar $<0.001$ dimana lebih kecil dari 0.005 dan koefisien jalur dengan tanda positif sebesar 0.336, maka dinyatakan significant sehingga Ha diterima dan Ho ditolak. Artinya lebih tinggi uang saku mahasiswa yang diterima maka literasi keuangan yang dimiliki mahasiswa juga lebih meningkat. Mahasiswa yang memiliki uang saku yang banyak harus dapat mengelola perilaku keuangannya dengan baik agar penggunaan uang saku yang dimilikinya sesuai dengan kebutuhan yang diperlukan.

Uang saku adalah pendapatan terbesar yang diterima mahasiswa dari orang tua. Menurut Yates dan Ward (dalam Egesta, 2019), seseorang dengan penghasilan tinggi akan memiliki literasi finansial yang semakin baik. Oleh karena itu kemampuan pelelolaan keuadangan dan perilaku keuangan mahasiswa yang menerima uang saku lebih banyak akan semakin baik karena mereka memiliki cukup banyak uang untuk dialokasikan ke hal-hal yang bermanfaat. Berbeda dengan Rachmasari (2018), yang mengemukakan bahwa literasi keuangan tidak dipengaruhi oleh pengiriman uang saku perbulan. Susanti et al. (2019), juga menyatakan hal yang sama dimana uang saku mempunyai pengaruh positif terhadap literasi keuangan.

Pengaruh Pembelajaran Akuntansi
Keuangan Terhadap Literasi Keuangan
Hasil analisis melalui Warppls menyatakan bahwa tidak memiliki pengaruh signifikan antara pembelajaran akuntansi keuangan dengan literasi keuangan. Dilihat dari $p$-value sebesar 0.160 dengan koefisien jalur 0.083 . Karena nilai $p$-value lebih tinggi dari 0.005 maka dinyatakan not significnat sehingga Ha ditolak dan Ho diterima. Artinya baik atau tidaknya pembelajaran akuntansi keuangan yang diperoleh mahasiswa tidak mempengaruhi literasi keuangan yang dimiliki.

\begin{tabular}{llr}
\multicolumn{1}{c}{ Menurut } & Widayati & (2014), \\
pembelajaran di perguruan & tinggi \\
memegang peranan penting & untuk
\end{tabular} membentuk literasi keuangan mahasiswa. Namun, hasil penelitian ini memperlihatkan jika literasi keuangan tidak dipengaruhi oleh pembelajaran akuntansi keuangan. Hal tersebut dikarenakan materi di dalam mata kuliah akuntansi keuangan lebih didominasi dengan pengelolaan keuangan entitas bisnis atau perusahaan dan tidak berkaitan dengan pengelolaan keuangan individu. Sehingga mahasiswa kurang mendapatkan pemahaman terkait literasi keuangan individu dari pembelajaran akuntansi keuangan. Tidak sejalan dengan Alimin (2018), yang mengungkapkan di perguruan 
tinggi pembelajaran mempengaruhi literasi keuangan secara signifikan.

\section{Pengaruh Pengalaman Kerja Terhadap Literasi Keuangan}

Hasil analisis melalui Warpp/s menunjukkan memiliki pengaruh positif dan signifikan antara pengalaman kerja kepada literasi keuangan terbukti dari nilai $p$-value sebesar $<0.001$ dimana lebih rendah dari 0.005 dan koefisien jalur dengan tanda positif sebesar 0.312 , maka dinyatakan significant sehingga $\mathrm{Ha}$ diterima dan $\mathrm{Ho}$ ditolak. Maka lebih banyak pengalaman kerja yang dimiliki mahasiswa maka tingkat literasi keuangan yang dimilikinya juga semakin tinggi dan sebaliknya semakin sedikit pengalaman kerja yang dimiliki maka tingkat literasi keuangan juga semakin rendah pula.

Menurut Shalahuddinta (2014), pengalaman kerja dapat meningkatkan pengetahuan keuangan yang dimiliki oleh seseorang. Dengan pengalaman kerja maka mahasiswa dapat belajar dan menyerap pengetahuan keuangan dari tempat kerjanya baik dari pengalaman pekerjaan yang sedang dikerjakannya maupun dari rekan kerja sehingga literasi keuangan yang dimilikinya dapat bertambah. Hasil penelitian ini konsisten dengan Irman \& Fadrul (2018), yang menyatakan pengalaman kerja menjadi pengaruh yang positif terhadap literasi keuangan.

\section{Pengaruh Literasi Keuangan Terhadap Perilaku Keuangan \\ Hasil analisis melalui Warpp/s} menunjukkan tidak mempunyai pengaruh yang signifikan antara literasi keuangan terhadap perilaku keuangan. Terbukti dari $p$ value sebesar 0.383 dengan koefisien jalur 0.025 . Karena nilai $p$-value lebih besar dari 0.005 maka dinyatakan not significnat sehingga Ho diterima dan Ha ditolak. Artinya mahasiswa dengan level literasi keuangan yang tinggi belum tentu memiliki perilaku keuangan yang semakin baik.

Busyro (2019), mengungkapkan jika literasi keuangan merupakan pemahaman dan keterampilan terkait keuangan yang dapat memudahkan seseorang dalam mengelola keuangan. Hasil penelitian memperlihatkan jika literasi keuangan tidak mempengaruhi perilaku keuangan. Ini terjadi karena mahasiswa dengan level literasi keuangan yang tinggi tidak mengaplikasikannya ke dalam pengelolaan keuangan pribadinya. Mereka hanya mengetahui teori-teori tentang keuangan tanpa mempraktikkan teori tersebut untuk mengelola keuangan pribadi. Hasil ini konsisten dengan Mandell \& Klein (2009), mengungkapkan jika literasi keuangan tidak dapat berpengaruh secara langsung terhadap perilaku keuangan jika pemahaman terkait keuangan yang terdapat dalam literasi keuangan tidak dipraktikkan langsung untuk mengelola keuangan pribadi. Namun hasil ini menolak Sholeh (2019), yang menyebutkan bahwa secara signifikan perilaku keuangan dipengaruhi oleh literasi keuangan.

Pengaruh Uang Saku Terhadap Perilaku
Keuangan dengan Literasi Keuangan
sebagai Variabel Intervening
Hasil uji efek mediasi pengaruh uang
saku terhadap perilaku keuangan yang dimediasi oleh literasi keuangan memperlihatkan jika nilai $p$-value sebesar 0.444 dengan indirect effects sebesar 0.009 . Sebab nilai $p$-value lebih besar dari 0.005 hingga dinyatakan not significant maka Ho diterima serta $\mathrm{Ha}$ ditolak. Artinya tidak memiliki pengaruh tidak langsung antara uang saku terhadap perilaku keuangan melalui literasi keuangan. Literasi keuangan tidak dapat menjadi variabel intervening karena tidak terdapat memediasi pengaruh uang saku terhadap literasi keuangan.

Mahasiswa dengan uang saku lebih tinggi dengan tingkat literasi keuangan yang tinggi juga belum tentu mempunyai perilaku keuangan dengan baik. Hal tersebut dapat terjadi jika mahasiswa tidak menerapkan literasi keuangan yang dimiliki untuk mengelola uang sakunya dengan bijak. Bahkan banyak mahasiswa yang mengerti mengenai literasi keuangan tetapi menggunakan uang sakunya secara tidak bertanggung jawab demi memenuhi keinginan dan bukan berdasarkan kebutuhan.

\section{Pengaruh Pembelajaran Akuntansi Keuangan Terhadap Perilaku Keuangan}


dengan Literasi Keuangan sebagai Variabel Intervening

Hasil uji efek mediasi pengaruh pembelajaran akuntansi keuangan terhadap perilaku keuangan yang dimediasi oleh literasi keuangan ditemukan nilai $p$-value sebesar 0.486 dengan indirect effects sebesar 0.002 . Sebab nilai $p$-value lebih tinggi dari 0.005 hingga dinyatakan not significnat sehingga $\mathrm{Ho}$ diterima serta $\mathrm{Ha}$ ditolak. Hingga bisa dikatakan jika literasi keuangan tidak mampu memediasi pengaruh pembelajaran akuntansi keuangan terhadap perilaku keuangan.

Mahasiswa dengan pembelajaran akuntansi keuangan yang baik dengan literasi keuangan yang tinggi belum tentu dapat berperilaku baik dalam mengelola keuangan. Pembelajaran akuntansi keuangan tidak dapat memberikan makna untuk mengelola keuangan pribadinya sehari-hari karena pembelajaran akuntansi keuangan yang didapatkan cenderung lebih banyak berkaitan dengan pengelolaan keuangan entitas bisnis atau perusahaan dan tidak berkaitan dengan pengelolaan keuangan pribadi. Hal ini menjadikan literasi keuangan mahasiswa tidak bertambah sehingga tidak menentukan perilaku keuangan mahasiswa. Hasil ini sesuai dengan Maulita \& Mersa (2017), yang mengungkapkan dengan ini tidak berdampak langsung pada pembelajaran di di perguruan tinggi kepada manajemen keuangan pribadi mahasiswa dengan variabel mediasi literasi keuangan. Rahayu (2019), juga mengemukakan bahwa pembelajaran di perguruan tinggi tidak mempengaruhi perilaku keuangan melalui financial literacy.

\section{Pengaruh Pengalaman Kerja Terhadap Perilaku Keuangan dengan Literasi Keuangan sebagai Variabel Intervening \\ Hasil uji efek mediasi pengaruh pengalaman kerja terhadap sikap keuangan yang termediasi oleh literasi keuangan. Dibuktikan dengan $p$-value sebesar 0.448 dan indirect effects sebesar 0.008. Sebab nilai $p$-value lebih tinggi dari 0.005 hingga dinyatakan not significnat sehingga $\mathrm{Ho}$ diterima serta Ha ditolak. Maksudnya literasi keuangan tidak memediasi pengaruh}

pengalaman kerja terhadap perilaku keuangan.

Pengalaman kerja memberikan tambahan pengetahuan dan keterampilan mahasiswa dalam mengelola keuangannya namun mahasiswa dengan pengalaman kerja dengan baik dan literasi keuangan yang tinggi belum menentukan perilaku keuangan yang baik. Hal itu dikarenakan kebanyakan mahasiswa hanya mengerti teori-teori keuangan tanpa mengimplementasikan teori tersebut dalam pengelolaan keuangan pribadi mereka

\section{SIMPULAN DAN SARAN}

Hasil pembahasan dan penelitian yang dilakukan peneliti, terkandung kesimpulan, yaitu: (1). Memiliki pengaruh langsung yang positif dan besar pada variabel uang saku terhadap perilaku keuangan mahasiswa Pendidikan Akuntansi UNESA, (2). Mempengaruhi pembelajaran akuntansi keuangan pada perilaku keuangan mahasiswa Pendidikan Akuntansi UNESA, (3). Memiliki dampak langsung yang positif dan besar dari pengalaman kerja terhadap perilaku keuangan mahasiswa Pendidikan Akuntansi UNESA, (4). Tidak mempengaruhi literasi keuangan pada perilaku mahasiswa Pendidikan Akuntansi UNESA, (5). Memiliki dampak langsung yang positif dan besar dari uang saku terhadap literasi keuangan mahasiswa Pendidikan Akuntansi UNESA, (6). Tidak memiliki pengaruh langsung pembelajaran akuntansi keuangan terhadap litreasi keuangan mahasiswa Pendidikan Akuntansi UNESA, (7). Tidak memiliki dampak langsung pada pengalaman kerja tentang literasi keuangan mahasiswa Pendidikan Akuntansi UNESA, (8). Literasi Keuangan tidak mengurangi dampak uang saku terhadap perilaku keuangan mahasiswa Pendidikan Akuntansi UNESA, (9). Litrasi Keuangan tidak memediasi dampak pembelajaran akuntansi keuangan terhadap perilaku keuangan mahasiswa Pendidikan Akuntansi UNESA, (10). Literasi keuangan tidak memediasi resultan pengalaman kerja terhadap perilaku keuangan mahasiswa Pendidikan Akuntansi UNESA.

Saran yang diberikan yaitu : (1). Mahasiswa diharapkan dapat meningkatkan literasi keuangan dan menerapkan 
pengetahuan terkait keuangan yang dimilikinya untuk mengelola keuangan pribadi. (2). Mahasiswa diharapkan memiliki pengalaman kerja yang lebih banyak agar perilaku keuangannya semakin baik, dan (3). Untuk peneliti lain jika hendak melakukan penelitian lebih lanjut, ada baiknya memakai faktor lain yang dapat memediasi pengaruh uang saku, pembelajaran akuntansi keuangan dan pengalaman kerja terhadap perilaku keuangan. Karena masih banyak faktor selain literasi keuangan yang dapat menjadi variabel intervening hubungan variabel tersebut.

\section{DAFTAR PUSTAKA}

Agustina, Nadia, \& Dkk. (2018). Pengaruh Kepuasan Pelanggan, Biaya Beralih, dan Kepercayaan Merek terhadap Loyalitas Pelanggan (Survei pada Pengguna Kartu Operator Seluler Simpati pada Mahasiswa Jurusan IImu Administrasi Bisnis Angkatan 2015/2016 dan 2016/2017 Fakultas IImu Administrasi. Jurnal Administrasi Bisnis (JAB), 64(1), 1-10.

Alimin, R. (2018). Pengaruh Pendidikan Keuangan Di Keluarga Dan Pembelajaran Di Perguruan Tinggi Terhadap Literasi Keuangan Mahasiswa Jurusan Akuntansi S1 Fakultas Ekonomi Universitas Negeri Makassar. 1492140006.

Andrew, Vincentius \& Linawati, N. (2014). Hubungan Faktor Demografi dan Pengetahuan Keuangan dengan Perilaku Keuangan Karyawan Swasta di Surabaya. Finesta, 2(01).

Arifin, A. Z. (2017). The influence of financial knowledge, control and income on individual financial behavior. European Research Studies Journal, 20(3), 635648.

Busyro, W. (2019). Pengaruh Literasi Keuangan Terhadap Perilaku Pengelolaan Keuangan Mahasiswa (Studi Kasus pada Mahasiswa Fakultas Ekonomi dan Bisnis Universitas Muhammadiyah Riau). Jurnal ISLAMIKA, 2(1).

Egesta, E. (2019). Faktor-Faktor yang Mempengaruhi Literasi Keuangan Mahasiswa (Studi pada Mahasiswa
Fakultas Ekonomi dan Fakultas Sains dan Teknologi Universitas Sanata Dharma Yogyakarta). Skripsi.

Erawati, N. (2016). Pengaruh Literasi Keuangan, Pembelajaran Di Perguruan Tinggi, Dan Pengalaman Bekerja Terhadap Perilaku Keuangan Mahasiswa Fakultas Ekonomi Universitas Negeri Surabaya. Jurnal Pendidikan Akuntansi (JPAK), 5(1), 17.

Erskine, M., Kier, C., Leung, A., \& Sproule, R. (2006). Peer crowds, work experience, and financial saving behaviour of young Canadians. 27, 262-284.

Fatimah, N., \& Syamsiyah, N. (2018). Proporsi Pengeluaran Rumah Tangga Petani Padi Di Desa Patimban, Kecamatan Pusakanagara, Kabupaten Subang, Jawa Barat Proportion of Household Expenditure of Rice Farmer in Patimban Village, Pusakanagara Subdistrict, Subang Regency, West Java. MIMBAR AGRIBISNIS: Jurnal Pemikiran Masyarakat Ilmiah Berwawasan Agribisnis, 4(2), 184.

Fatimah, S. (2018). Pengaruh Pembelajaran Akuntansi Keuangan, Literasi Keuangan, Dan Pendapatan Terhadap Perilaku Keuangan Mahasiswa Fakultas Ekonomi Universitas Muhammadiyah Gresik. JPKA: Jurnal Pendidikan Akuntansi., 6(01).

Garman \& Forgue. (2010). Personal Finance International Edition. South Western Cengage Learning, Canada.

Herawati, N. T. (2015). Kontribusi pembelajaran di perguruan tinggi dan literasi keuangan terhadap perilaku keuangan mahasiswa. Jurnal Pendidikan Dan Pengajaran, 1-3(48), 60-70.

Imawati, I. (2013). Pengaruh Financial Literacy Terhadap Perilaku Konsumtif Remaja pada Program IPS SMA Negeri 1 Surakarta Tahun Ajaran 2012/2013. Jupe UNS, 2(1).

Irman \& Fadrul. (2018). Analisis Pengaruh Jenis Kelamin, IPK, Dan Pengalaman Kerja Terhadap Tingkat Financial Literacy. Journal of Economic, Business and Accounting (COSTING), 2(01). 
Irman, M. (2018). Analisis Faktor-Faktor Yang Mempengaruhi Financial Literacy di Kalangan Mahasiswa Universitas Muhammadiyah Riau (UMRI) Pekanbaru. Journal of Economic, Business and Accounting (COSTING), 1(02).

Kumalasari, S. (2019). Pengaruh Literasi Keuangan, Modernitas Individu, Uang Saku Dan Kontrol Diri Terhadap Perilaku Konsumtif Mahasiswa Prodi S1 Pendidikan Ekonomi Angkatan Tahun 2016 Fakultas Ekonomi Universitas Negeri Malang. Jurnal Pendidikan Ekonomi, 12(1), 61-71.

Laily, N. (2014). Pengaruh literasi keuangan terhadap perilaku mahasiswa dalam mengelola keuangan. Jurnal Pendidikan Akuntansi. Universitas Negeri Malang.

Lina, \& Rosyid, H. . (1997). Perilaku Konsumtif berdasar Locus Of Control pada Remaja Putri. Jurnal Psikologika, 4, 5-13.

Malhotra, N. K. (2005). Riset Pemasaran: Pendekatan Terapan. PT. Indeks.

Mandell, L., \& Klein, L. S. (2009). The Impact of Financial Literacy Education on Subsequent Financial Behavior. 206, 15-24.

Maulita \& Mersa. (2017). Pengaruh Literasi Keuangan Terhadap Pengelolaan Keuangan Pribadi pada Mahasiswa di Politeknik Negeri Samarinda. SNITT Politenik Negeri Balikpapan.

Megasari, I. R. (2014). Pembelajaran Pengelolaan Keuangan Orang Tua, Uang Saku, dan Hasil Belajar Terhadap Literasi Keuangan di SMK PGRI 3 Sidoarjo. Jurnal Ekonomi Pendidikan Dan Kewirausahaan, 2(2).

Nanang, M. (2011). Metode penelitian Kuantitatif Analisis Isi dan Analisis Data Sekunder. Jakarta: Raja GRafindo Persada.

Nasihah, L. (2019). Pengaruh Pembelajaran Akuntansi Keuangan, Literasi Keuangan, dan Kontrol Diri Terhadap Perilaku Keuangan Mahasiswa Fakultas Ekonomi Universitas Negeri Surabaya. JPKA: Jurnal Pendidikan Akuntansi., 7(03).

Nidar, S. R., \& Bestari, S. (2012). Personal Financial Literacy Among University
Students (Case Study at Padjadjaran University Students. World Journal of Social Science, 2(4), 162-171.

Rachmasari, A. (2018). Faktor-faktor yang Mempengaruhi Literasi Keuangan Mahasiswa. Skripsi.

Rahayu, M. (2019). Pengaruh Pembelajaran di Perguruan Tinggi, Financial Attitude, Locus Of Control dan Pendidikan Keluarga Terhadap Perilaku Keuangan Melalui Financial Literacy Sebagai Variabel Intervening (Studi Kasus Mahasiswa Fakultas Ekonomi Universitas Negeri Semarang. Skripsi.

Rizkiana \& Kartini. (2017). Analisis Tingkat Financial Literacy dan Financial Behaviour Mahasiswa S1 Fakultas Ekonomi Universitas Islam Indonesia. 7(1).

Sabri, M. (2008). Financial Behavior and Problems Among College Students in Malaysia. Research and Education Implication Consumer Interest Annual 54.

Sagita, A. A., Susilo, H., \& Cahyo, M. (2018). PENGARUH BUDAYA ORGANISASI TERHADAP KINERJA KARYAWAN DENGAN MOTIVASI KERJA SEBAGAI VARIABEL MEDIATOR (Studi Pada PT Astra Internasional, Tbk-Toyota (Auto2000) Cabang Sutoyo Malang). Jurnal Administrasi Bisnis (JAB), 57(1), 73-82.

Sari, D. A. (2015). Finalcial Literacy dan Perilaku Keuangan Mahasiswa (Studi Kasus Mahasiswa Stie 'YPPI' Rembang). Buletin Bisnis Dan Manajemen, 01(02).

Shalahuddinta, A. (2014). Pengaruh Pendidikan Keuangan di Keluargam Pengalaman Bekerja dan Pembelajaran di Perguruan Tinggi terhadap Literasi Keuangan. Universitas Negeri Surabaya. JPKA: Jurnal Pendidikan Akuntansi.

Sholeh, B. (2019). Pengaruh Literasi Keuangan Terhadap Perilaku Keuangan Mahasiswa Program Studi Pendidikan Ekonomi Universitas Pamulang. PEKOBIS: Jurnal Pendidikan, Ekonomi Dan Bisnis, 4(2).

Sina, P. G. (2014). Motivasi Sebagai Penentu Perencanaan Keuangan (Suatu Studi Pustaka). Jurnal IImiah 
Akuntansi Dan Bisnis, 9(1).

Suryani \& Hendryadi. (2015). Metode Riset Kuantitatif Teori dan Aplikasi pada Penelitian Bidang Manajemen dan Ekonomi Islam. Prenada Media Group.

Susanti. (2013). Faktor - Faktor yang Mempengaruhi Literasi Keuangan Mahasiswa Fakultas Ekonomi Universitas Negeri Surabaya. Jurnal Pendidikan Ekonomi: Universitas Negeri Malang.

Susanti, N., Rahmayanti, R., Padmakusumah, R. R., \& Susanto, R. (2019). Factors Affecting Students Financial Literation: A Study on Widyatama University, Indonesia. Universal Journal of Educational Research, 7(5A), 7-14.

Vhalery, rendika, Aimon, H., \& Yulhendri, Y. (2018). The Management of Student's Pocket Money. 8(1), 10-15.

Widayati, I. (2014). Pengaruh Status Sosial Ekonomi Orang Tua, Pendidikan Pengelolaan Keuangan Keluarga , dan Pembelajaran di Perguruan Tinggi terhadap Literasi Finansial Mahasiswa. Jurnal Pendidikan Humaniora, 2(2), 176-183.

Zulaika, L. (2020). Literasi Keuangan , Uang Saku, Kontrol Diri , dan Teman Sebaya Terhadap Perilaku Menabung Mahasiswa. EKUITAS: Jurnal Pendidikan Ekonomi, 8(2), 137-146. 